九州大学学術情報リポジトリ

Kyushu University Institutional Repository

Glycolate Synthesis in Tomato Leaf Disks:

Involvement of Storage Material in

Photorespiration

Yamauchi, Minoru

Laboratory of Soil Fertility and Plant Nutrition, Faculty of Agriculture, Kyushu University

Yamada, Yoshio

Laboratory of Soil Fertility and Plant Nutrition, Faculty of Agriculture, Kyushu University

https://doi.org/10.5109/23819

出版情報：九州大学大学院農学研究院紀要. 30 (2/3)，pp. 135-147，1985-12. Kyushu University バージョン：

権利関係 : 
J. Fac. Agr., Kyushu Univ., 30 (2 • 3), 135-147 (1985)

\title{
Glycolate Synthesis in Tomato Leaf Disks: Involvement of Storage Material in Photorespiration
}

\author{
Minoru Yamauchi* and Yoshio Yamada \\ Laboratory of Soil Fertility and Plant Nutrition, Faculty of Agriculture, \\ Kyushu University 46-02, Fukuoka 812
}

(Received September 9, 1985)

\begin{abstract}
Glycolate accumulated in tomato leaf disks in the presence of $\alpha$-hydroxy 2-pyridinemethanesulfonic acid during photosynthesis in the presence of ${ }^{14} \mathrm{CO}_{2}$. Based on the specific radioactivities of the glycolate and $\mathrm{CO}$, and the amount of ${ }^{14} \mathrm{C}$ in the glycolate pool, the amounts of glycolate and glycolate originating from $\mathrm{CO}$, fixation were calculated. At $21 \% \mathrm{O}_{2}$, the glycolate accumulation increased with increasing $\mathrm{CO}$, concentration to a maximum at $200-400 \mathrm{ppm}$ but was inhibited when the $\mathrm{CO}_{2}$ level was raised further. The accumulation of glycolate originating from $\mathrm{CO}$, was reduced and the specific activity of glycolate relative to the added $\mathrm{CO}$, decreased significantly at low CO, concentration. These findings suggest that at low CO, concentration, the main source of glycolate carbon is in the storage material. Glycolate formation and its carbon sources were further analyzed by varying the $\mathrm{O}_{2} /$ $\mathrm{CO}$, ratio in the atmosphere, temperature and light intensity. The results suggested that glycolate is synthesized from storage materal when the $\mathrm{O}_{2} / \mathrm{CO}_{2}$ ratio in the atmosphere is high and that decreased photosynthesis restricts the synthesis of glycolate originating from $\mathrm{CO}$,
\end{abstract}

\section{INTRODUCTION}

The glycolate pathway is responsible for photorespiration. The substrate of the pathway, glycolate, is synthesized mainly through oxygenation of RuBP" (Andrews and Lorimer, 1978). 0, competes with $\mathrm{CO}_{2}$ at the catalytic site of RuBP carboxylase/oxygenase. Experiments with intact chloroplasts have revealed that a high $\mathrm{O}_{2} / \mathrm{CO}_{2}$ ratio favors glycolate synthesis (Ellyard and Gibbs, 1969; Robinson and Gibbs, 1974).

In intact leaves, however, determination of glycolate synthesis is difficult, because of the high activity of glycolate oxidase. Zelitch and Walker (1964) reported that glycolate accumulation in tobacco leaves decreased at high $\mathrm{CO}_{2}$ concentrations in the presence of $\mathrm{HPMS}^{2)}$, an inhibitor of glycolate oxidase. Lee and Whittingham (1974) also found that ${ }^{14} \mathrm{CO}_{2}$ incorporation into the glycolate pathway decreased at high $\mathrm{CO}_{2}$ concentrations. On the other hand,

* Present address: Rice Research Program, International Institute of Tropical Agricuture, Oyo Road, PMB 5320, Ibadan, Nigeria.

1) RuBP, ribulose-1, 5-biphosphate

2) HPMS, $\alpha$-hydroxy 2-pyridinemethanesulfonic acid 
Bravdo and Canvin (1979) reported that rates of photorespiration decreased little at high $\mathrm{CO}_{2}$ concentrations. Yamauchi and Yamada (1981) suggested that the ${ }^{14} \mathrm{CO}_{2}$ incorporation into the glycolate pathway, as measured by ${ }^{14} \mathrm{C}$ entering the serine pool, was substantial at high $\mathrm{CO}$, concentrations. The effect of $\mathrm{CO}_{2}$ concentration on the glycolate pathway thus remains unclear.

When " $\mathrm{CO}$, was applied to illuminated leaves, the specific radioactivity of glycolate was about 50 to $100 \%$ of the ${ }^{14} \mathrm{CO}_{2}$ (Zelitch, 1975; Agrawal and Fock, 1978), suggesting that the carbon of $\mathrm{CO}_{2}$ fixed during photosynthesis is a principal source of glycolate carbon. However, Ludwig and Canvin (1971) and Fock et al. (1979) reported that the specific activity of photorespired CO, decreased at lower $\mathrm{CO}_{2}$ concentrations. The amount of ${ }^{14} \mathrm{CO}_{2}$ incorporated into the glycolate pathway was found by us to decrease at lower $\mathrm{CO}_{2}$ concentrations (Yamauchi and Yamada,1981), where substantial glycolate is formed (Oliver, 1979). It is proposed that storage material is involved in pohotorespiration at low CO, concentrations (Mahon et al., 1974 a; Beck, 1979, Yamauchi and Yamada, 1981, 1982).

In the present study, glycolate was accumulated in tomato leaf disks by blocking its oxidation with HPMS (Zelitch, 1973) during photosynthesis in ${ }^{14} \mathrm{CO}_{2}$. The amounts of glycolate and glycolate whose carbon source was in photosynthetically fixed $\mathrm{CO}$, werer calculated on the basis of the specific activities of glycolate and $\mathrm{CO}$, and of the amount of ${ }^{14} \mathrm{C}$ in the glycolate pool. Furthermore, the specific actvity of glycolate was compared with that of $\mathrm{CO}$, in order to evaluate the photosynthetically fixed carbon in glycolate synthesis. It is suggested that storage material is involved in glycolate synthesis in an atmosphere of high $\mathrm{O}_{2} / \mathrm{CO}_{2}$ ratio.

\section{MATERIALS AND METHODS}

\section{Plant materials}

Tomato plants (Lycopersicon esculentum Mill cv. Fukuju No. 2) were grown under natural light in solution culture (Yamauchi and Yamada, 1980). $\mathrm{NaNO}_{3}$ was used as the nitrogen source. Young fully-developed 6 th or 7 th leaves (6 to 8 weeks old) were detached under water and stored with their cut bases in water at room temperature $\left(20-25^{\circ} \mathrm{C}\right.$ ) in the dark until use (less than 12 h).

\section{Gas exchange apparatus and techniques of glycolate accumulation}

After oxygen and/or nitrogen gas had been admitted into a Tedlar bag (Du Pont Co., Ltd.) of 20 or 100 liters, the desired proportion of $\mathrm{CO}$, or ${ }^{14} \mathrm{CO}_{2}$ was introduced into the bag. The $\mathrm{CO}$, or ${ }^{14} \mathrm{CO}_{2}$ had been prepared by adding lactic acid to $\mathrm{Na}_{2} \mathrm{CO}_{3}$ or $\mathrm{Na}_{2}{ }^{14} \mathrm{CO}_{3}$. The gas mixture was prepared just before use. The ${ }^{14} \mathrm{C}$ in a unit volume of the ${ }^{14} \mathrm{CO}_{2}$-gas mixture was determined by liquid scintillation counting after dissolving the ${ }^{14} \mathrm{CO}_{2}$ in an ethanolamine-methyl cellosolve mixture (1: $3, \mathrm{v} / \mathrm{v})$. The concentration of $\mathrm{CO}_{2}$ was measured with an infrared $\mathrm{CO}_{2}$ analyzer. The specific radioactivity of ${ }^{14} \mathrm{CO}_{2}$ was calculated from the ratio of two values. 
Glycolate was accumulated by the method of Zelitch (1973) and Oliver (1979). Nine disks ( $1.5 \mathrm{~cm}$ in diameter, about $0.245 \mathrm{~g}$ fr wt) per sample were punched from the detached leaves, strung together on a thread and placed in the bottom of a $100-\mathrm{ml}$ Erlenmeyer flask. The disks were then washed with $5 \mathrm{ml}$ of water 2 to 3 times and floated on $5 \mathrm{ml}$ of water. The flask was placed in an illuminated water bath at a prescribed temperature (see figure legends). A rubber stopper with two glass tubes and two long hollow needles was used to stopper the flask. Gas was exchanged through the glass tubes. The hollow needles, attachable to syringes, were used to remove the water and to add $10 \mathrm{mM}$ HPMS solution, on which the disks floated.

The gas mixture of ${ }^{14} \mathrm{CO}_{2}$ with the desired composition of $\mathrm{O}_{2}, \mathrm{~N}_{2}$ and $\mathrm{CO}$,

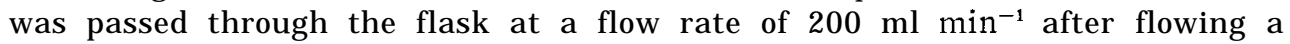
${ }^{12} \mathrm{CO}_{2}$ gas mixture of the same composition for $30 \mathrm{~min}$. APS ${ }^{3)}$ was determined by measuring the decrease in ${ }^{14} \mathrm{CO}_{2}$ concentration and was stable during the " $\mathrm{CO}$, application. After application of the ${ }^{14} \mathrm{CO}_{2}$ for $30 \mathrm{~min}$, the water in the flask was removed and replaced with $5 \mathrm{ml}$ of $10 \mathrm{mM}$ HPMS through the needle. The flask was then shaken gently once. The flow of the ${ }^{14} \mathrm{CO}_{2}$-gas was stopped and the flask was opened $170 \mathrm{~s}$ after the injection of HPMS. The disks were removed at $180 \mathrm{~s}$ using the thread and killed in $15 \mathrm{ml}$ of boiling $20 \%$ ethanol.

Preliminary tests (Yamauchi, 1982) revealed that glycolate accumulated linearly for at least $180 \mathrm{~s}$ after the application of HPMS. The specific activity of glycolate accumulated following HPMS application increased after starting photosynthesis in ${ }^{14} \mathrm{CO}_{2}$ and reached a stable value before $30 \mathrm{~min}$.

\section{Analysis of the concentration and specific activitity of glycolate}

The killed disks were homogenized in $20 \%$ ethanol with a glass homogenizer. The homogenate was filtered through a glass filter with the aid of hyflo super-cell under reduced pressure. The filtrate was passed through a Dowex 1 x8 (200-400 mesh) acetate column (1. Ox $10 \mathrm{~cm})$. Glycolate was eluted from the column with $50 \mathrm{ml}$ of $4 \mathrm{M}$ acetic acid (glycolate fraction). This contained glycolate, glycerate and unknown compounds which can hinder color development in Calkins' test (Calkins, 1943). The glycolate concentration in the glycolate fraction was therefore not obtained directly by the test. It was calculated on the basis of the amount of ${ }^{14} \mathrm{C}(\mathrm{dpm})$ in and the specific activity $(\mathrm{dpm} / \mu \mathrm{mol})$ of glycolate, which were measured as described below.

The glycolate fraction was concentrated under reduced pressure at $40^{\circ} \mathrm{C}$ to $1 \mathrm{ml}$. The recovery of glycolate in the concentrated fraction, which was measured by adding a known amount of $1{ }^{14} \mathrm{C}$-glycolate to the killed leaf disks, was about $95 \%$.

The amount of ${ }^{14} \mathrm{C}$ in the glycolate in the glycolate fraction was measured as follows. A portion of the concentrated glycolate fraction was spotted on Whatman 3 MM paper together with carrier glycolic acid $(25-50 \mu l$ of $10 \mathrm{mg} / \mathrm{ml}$ aqueous solution) because glycolate is volatile. It was developed by ascending

3) APS, apparent photosynthesis 
chromatography for $18 \mathrm{~h}$ at room temperature with ethylether/acetic acid/water (15: 3: 1, v/v). After development, the chromatograms were dried at room temperature, and the glycolic acid was located by spraying with $0.04 \%$ bromocresol green ( $\mathrm{pH}$ 7.0). The glycolate was eluted from the paper with water and its ${ }^{14} \mathrm{C}$ was determined by liquid scintillation counting. Above $95 \%$ of $1 .{ }^{14} \mathrm{C}$-glycolate, which had been spotted on the paper with the carrier, was recovered by this procedure.

The amount of glycolate formed from $\mathrm{CO}$, (namely ${ }^{14} \mathrm{CO}_{2}$ and ${ }^{12} \mathrm{CO}_{2}$ ) was calculated on the basis of the amount of ${ }^{14} \mathrm{C}(\mathrm{dpm})$ in the glycolate and the specific activity (dpm/ $\mu \mathrm{mol})$ of the ${ }^{14} \mathrm{CO}_{2}$ applied.

The specific activity of glycolate was determined as follows: The concentrated glycolate fraction from the Dowex 1 column was subjected to paper chromatography without carrier to remove the hindering substances of Calkins' test. ${ }^{14} \mathrm{C}$-glycolate was eluted with water from the chromatogram, and its concentration was then determined by Calkins' test and its ${ }^{14} \mathrm{C}$ by liquid scintillation counting. The specific activity of glycolate was calculated from these two values.

Preliminary tests confirmed the accuracy of values for the specific activity of glycolate obtained by this method. When $0.26 \mu \mathrm{mol}$ of glycolic acid (2.50 $10^{5} \mathrm{dpm} \mu \mathrm{mol}^{-1}$ ) was chromatographed, its specific activity was lowered to 85 $\%$ of the initial value, as an average of two determinations. On the other hand, the specific activity of glycolate in different volumes of tomato leaf extract was determined after adding a constant amout of 1-“'C glycolic acid (Fig. 1). This control test revealed that the reciprocal of the specific activity of glycolate varied linearly over the range of one-fifth to two times the amount of glycolate accumulated per sample in normal air. This indicated that the method used to determine the specific activity was valid for comparisons over this range of glycolate, although there was an error in the absolute values of the specific activity. When a serious error was expected in measuring the specific activity of glycolate, it will be specified in the text.

\section{RESULTS AND DISCUSSION}

The relative specific activity (RSA) of glycolate was expressed as:

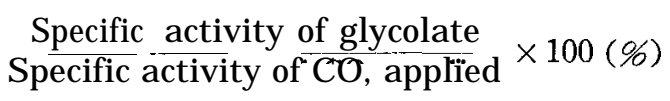

When glycolate is synthesized from photosynthetically fixed CO, RSA becomes $100 \%$. A decrease in RSA means that part of the glycolate originates from a source other than the fixed $\mathrm{CO}_{2}$.

The glycolate accumulation rate in the presence of $\mathrm{HPMS}$ at $21 \% \mathrm{O}_{2}$ was about $40 \mu \mathrm{mol} \mathrm{g}$ fr $\mathrm{wt}^{-1} \mathrm{~h}^{-1}$ (calculated from Fig. 2). The glycolate synthesis in the tomato leaf disks was also evaluated from the $\mathrm{CO}$, efflux into $\mathrm{CO}$,-free air. The $\mathrm{CO}_{2}$ efflux rate was found to be about $31 \mu \mathrm{mol} \mathrm{g} \mathrm{fr} \mathrm{wt}^{-1} \mathrm{~h}^{-1}$ in the light and about $19 \mu \mathrm{molg}$ fr $\mathrm{wt}^{-1} \mathrm{~h}^{-1}$ in the dark. If one assumes that all the 


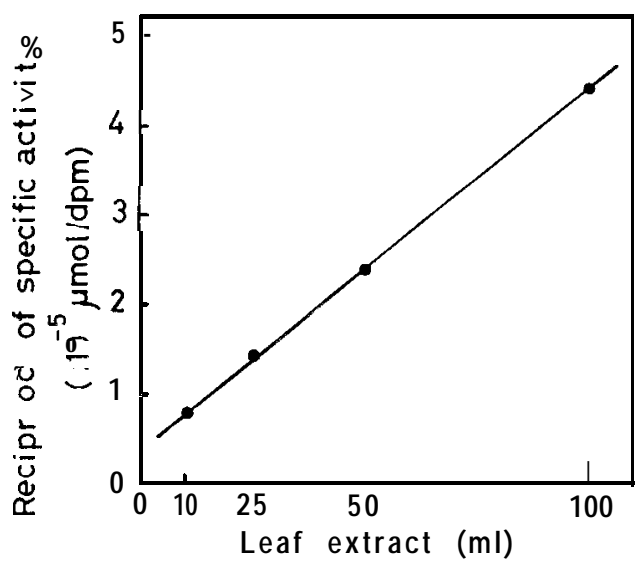

Fig. 1. Control tests of the method for determining the specific activity of glycolate.

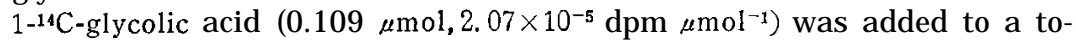
mato leaf extract of $10,25,50$ or $100 \mathrm{ml}$. The specific activity of glycolate in each extract was then determined by the method described under Materials and Methods. The tomato extract was from leaf disks treated in air for $180 \mathrm{~s}$ with HPMS. Fifty $\mathrm{ml}$ of the leaf extract corresponded to one sample analysis in other experiments. The ordinate represents the reciprocal of the specific activity.

$\mathrm{CO}$, released in the light originates from the glycolate pathway and that 2 glycolates from $1 \mathrm{CO}$, and serine (Tolbert, 1971), the glycolate synthesis could be as high as $62 \mu \mathrm{mol} \mathrm{g} \mathrm{fr} \mathrm{wt}^{-1} \mathrm{~h}^{-1}$. If it is assumed that the CO, released in the light contained dark respiration, then the $\mathrm{CO}$, release from photorespiration would be $12 \mu \mathrm{mol} \mathrm{g}$ fr $\mathrm{wt}^{-1} \mathrm{~h}^{-1}$. The glycolate accumulation rate is within the range estimated from the $\mathrm{CO}_{2}$ efflux.

The extent of HPMS penetration into the tissue is obscure in our method of glycolate accumulation. Moreover, HPMS inhibits enzymes other than glycolate oxidase and reduces the photosynthesis rate (Liittge et al., 1972). However, the glycolate accumulation rate is sufficient to explain the degree of photorespiration, which is obtained only when HPMS is applied to the leaf tissue (Zelitch, 1979). Although the detailed mechanism of glycolate accumulation in HPMS-treated leaf disks has not yet been clarified, this method could be useful in glycolate synthesis studies on intact leaf tissues.

At $21 \% \mathrm{O}_{2}$, APS increased with increasing $\mathrm{CO}$, concentration up to 1000 ppm (Fig. 2). The RSA of glycolate was maximum (92-94 \%) at 200-500 ppm $\mathrm{CO}$, and minimum at low $\mathrm{CO}$, concentration. The RSA decreased with increasing $\mathrm{CO}_{2}$ concentrations above $525 \mathrm{ppm}$. The effect of $\mathrm{CO}_{2}$ concentration on the RSA of glycolate was consistent with those of glycine and serine, intermediates in the glycolate pathway, reported by Mahon et al. $(1974$ a). The striking decrease in RSA of glycolate at low $\mathrm{CO}_{2}$ concentrations indicates that there is a glycolate carbon source other than photosynthesis.

Glycolate accumulation increased with increasing $\mathrm{CO}_{2}$ concentration to a 


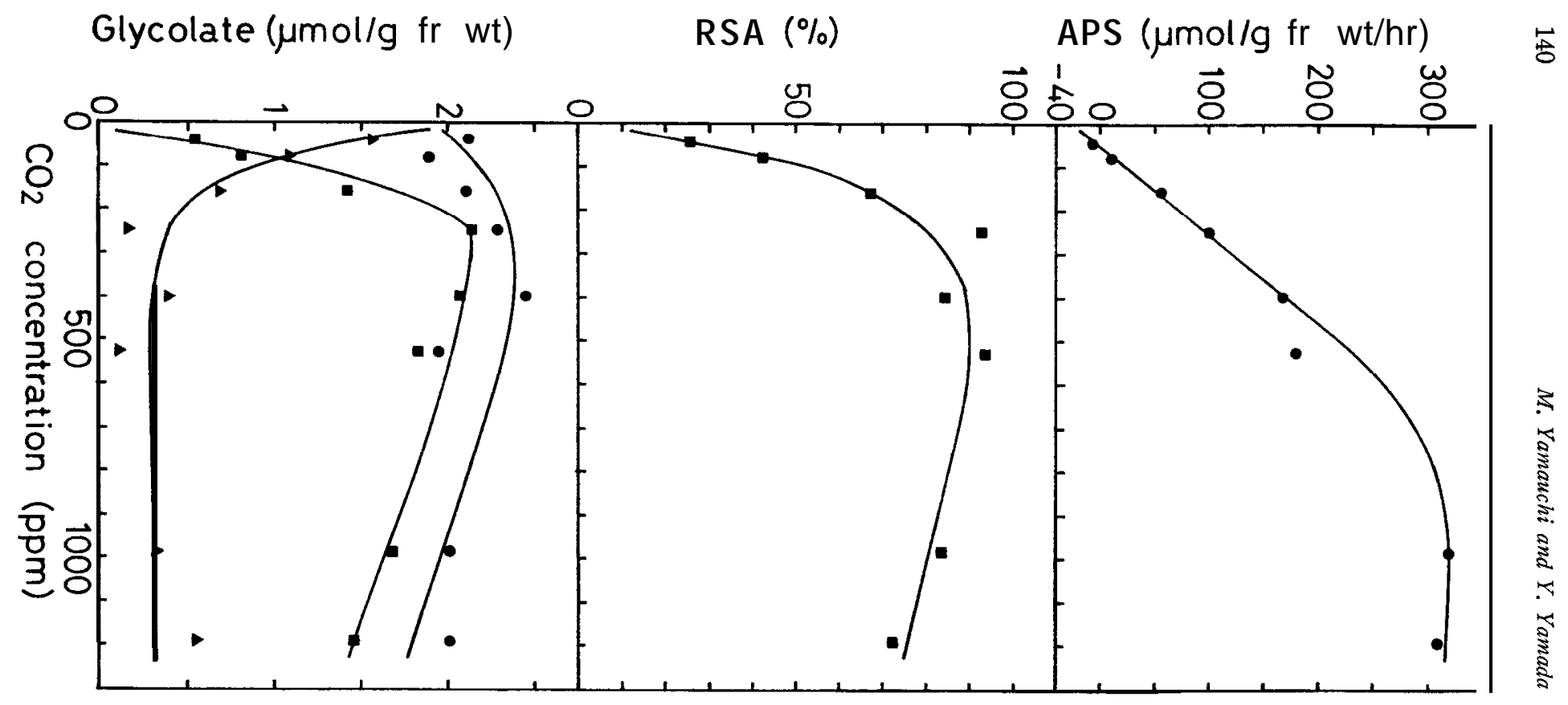

Fig. 2. Effects of CO, concentration on APS“ RSA of glycolate and its accumulation.

In the lower graph, $\boldsymbol{\Delta}$ indicates the difference in accumulation of glycolate (O) and glycolate whose carbon was from photosynthetically fixed CO

(D). A flask with 9 disks was immersed in a water bath at $25^{\circ} \mathrm{C}$. The photon flux density at the surface of the disks was $600-660 \mu \mathrm{Em}^{-2} \mathrm{~s}^{-1}$. The disks in $21 \% 0$, were maintained in $\mathrm{CO}$, for $30 \mathrm{~min}$ and in ${ }^{14} \mathrm{CO}_{2}$ at the same concentration for the following $30 \mathrm{~min}$. Then, $10 \mathrm{mM}$ HPMS was applied to the disks for $180 \mathrm{~s}$. The concentrations (ppm) and specific activities of ${ }^{14} \mathrm{CO}_{2}\left(\mathrm{dpm} \mu \mathrm{mol}^{-1}\right)$ applied to the disks were as follows: 44 , $1.94 \times 10^{6} ; 78, \quad 1.30 \times 10^{6} ; 158, \quad 7.37 \times 10^{5} ; 249, \quad 7.63 \times 10^{5} ; 396, \quad 6.09 \times 10^{5} ; 525$,

$4.70 \times 10^{5} ; 985,5.41 \times 10^{5} ;$ and $1190,3.84 \times 10^{5}$, respectively 
maximum at $\mathbf{Z 0 0 - 4 0 0 ~ p p m ~} \mathrm{CO}_{2}$, and was then slightly reduced at higher $\mathrm{CO}$, levels (Fig. 2). The glycolate accumulation from $\mathrm{CO}_{2}$ was greatly lowered with decreasing $\mathrm{CO}_{2}$ concentrations below $249 \mathrm{ppm}$, but its ratio to APS increased with such decreasing $\mathrm{CO}$, concentration. The increased differences in accumulations of glycolate from $\mathrm{CO}_{2}$ at lower $\mathrm{CO}_{2}$ concentrations also indicate that there is a glycolate carbon source other than photosynthesis. The storage material represents a probable carbon source for glycolate synthesis. In the following discussion, therefore, we assume that glycolate carbon source other than photosynthetically fixed $\mathrm{CO}$, was the storage material, and investigate its involvement in glycolate synthesis under various conditions.

APS decreased linearly with increasing 0 , concentration in the range of 435 to $507 \mathrm{ppm} \mathrm{CO}$ (Fig. 3). The RSA of glycolate increased to a maximum between 25 and $50 \% \mathrm{O}_{2}$ and then decreased with increasing 0 , concentrations. The decrease in the RSA of glycolate when the $\mathrm{O}_{2}$ concentration was lowered to $1 \%$ agrees with those of glycine and serine in sunflower leaves (Mahon et al., 1974 b). The amount of glycolate accumulated at $0 \% \mathrm{O}_{2}$, being $0.259 \mu \mathrm{mol} \mathrm{g} \mathrm{fr} \mathrm{wt}^{-1}$, was too small for accurate measurement of its specific activity. The amount of glycolate from $\mathrm{CO}_{2}$ decreased with increasing $\mathrm{O}_{2}$ concentration above $25 \%$, but its ratio to APS increased. The glycolate from storage material increased with increasing 0 , concentration.

Fig. 4 shows the effects of 0 , concentration on APS and glycolate accumulation as a function of $\mathrm{CO}$, concentration. The difference in glycolate accumulation from $\mathrm{CO}$, between $1 \%$ and $80 \% 0$, was negligible at a low $\mathrm{CO}$, concentration, but increased at high $\mathrm{CO}$, concentrations. Storage material was involved in the glycolate accumulation at the lower $\mathrm{CO}$, concentration and 80 $\% \mathrm{O}_{2}$, but not at $1 \% \mathrm{O}_{2}$.

The effects of temperature on APS, RSA, and accumulation of glycolate were examined at $386 \mathrm{ppm} \mathrm{CO}_{2}$ and $21 \% \mathrm{O}_{2}$ (Fig. 5). APS was maximum between 25 and $35^{\circ} \mathrm{C}$. The RSA of the glycolate was not appreciably influenced by temperature over the range of 15 to $30^{\circ} \mathrm{C}$, being 74 to $81 \%$. This is consistent with the report of Fock et al. (1979) that the RSA of photoperiod CO, is independent of leaf temperature in the range of 18 to $30^{\circ} \mathrm{C}$. Glycolate accumulation from storage material was slightly increased between 25 and $39^{\circ} \mathrm{C}$. Glycolate accumulation was maximum between 25 and $35^{\circ} \mathrm{C}$ as well as APS.

The effect of light intensity on APS, RSA, and accumulation of glycolate was also examined at $450 \mathrm{ppm} \mathrm{CO}$, and $21 \% \mathrm{O}_{2}$ (Fig. 6). The glycolate accumulation increased with increasing light intensity as well as APS. Increasing light did not increase the glycolate accumulation from storage material at an intensity of up to $963 \mu \mathrm{E} \mathrm{m}^{-2} \mathrm{~S}^{-1}$. The RSA of glycolate was constant except at an extremely low light intensity.

It has been established that glycolate synthesis in intact chloroplast is regulated by the ratio of $\mathrm{O}_{2} / \mathrm{CO}_{2}$ (Ellyard and Gibbs, 1969; Robinson and Gibbs, 1974). In tomato leaf disks, glycolate synthesis was decreased at high CO, and/ or low $\mathrm{O}_{2}$ concentrations (Figs. 2-4), which is consistent with studies using organellae. However, the glycolate synthesis from photosynthetically fixed $\mathrm{CO}_{2}$ was decreased at low $\mathrm{CO}$, and/ or high $\mathrm{O}_{2}$ concentrations (Figs. 2-4), 


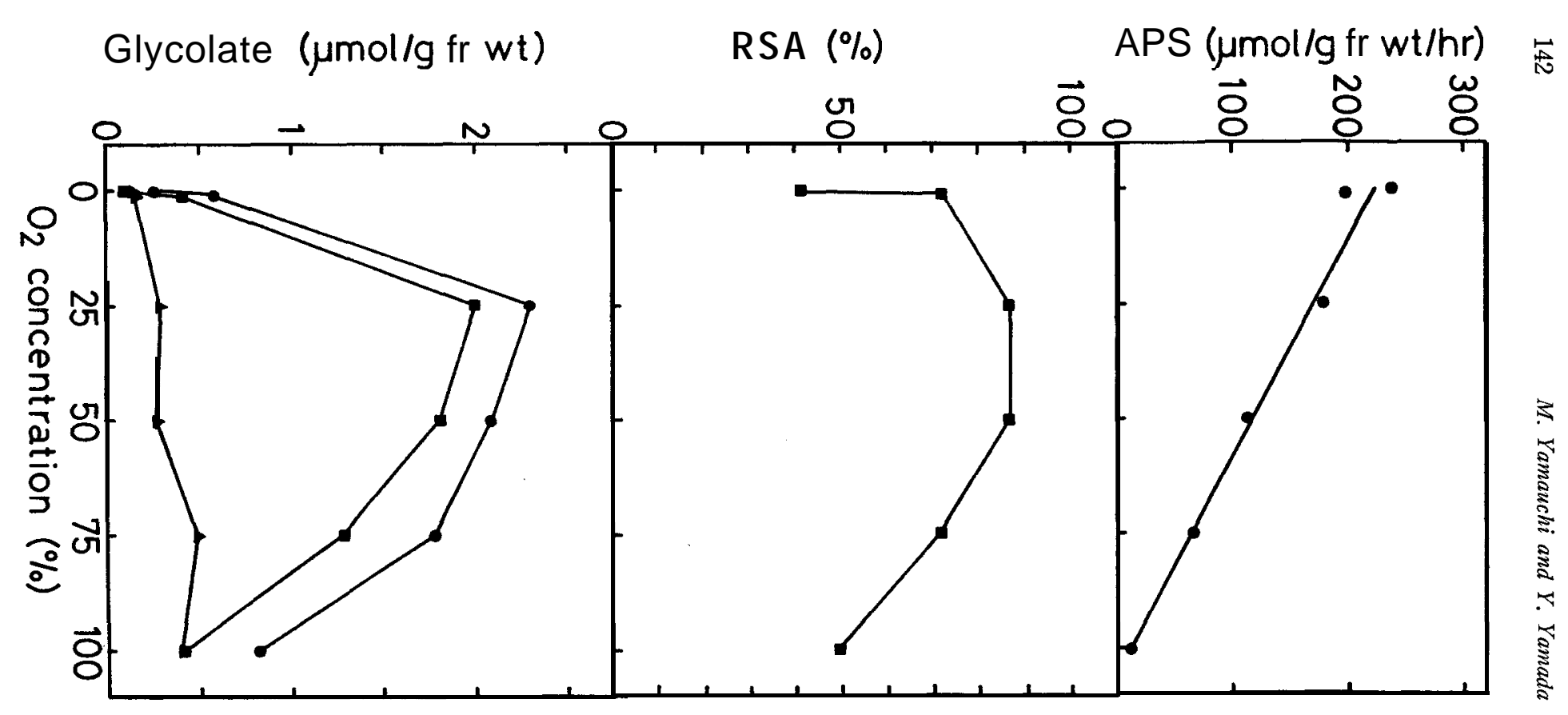

Fig. 3. Effects of 0 , concentration on APS, RSA of glycolate and its accumulation in tomato leaf disks.

$\boldsymbol{\Delta}$ indicates the differnce in accumulations of glycolate (O) and glycolate whose carbon was from photosynthetically fixed $\mathrm{CO}_{2}\left(D_{0}\right.$. A flask with 9 disks was immersed in a water bath at $29^{\circ} \mathrm{C}$. The photon flux density at the surface of the disks was $600-660 \mu \mathrm{E} \mathrm{m}^{-2} \mathrm{~s}^{-1}$. Before the application of ${ }^{14} \mathrm{CO}_{2}$ at the desired 0 , concentration, the disks were maintained in ${ }^{12} \mathrm{CO}_{2}$ at the respective $\mathrm{O}_{2}$ concentration for $30 \mathrm{~min}$. After $30 \mathrm{~min}$ photosynthesis in ${ }^{14} \mathrm{CO}_{2}$, the disks were treated with HPMS for $180 \mathrm{~s}$. The concentration of $0,(\%)$ and $\mathrm{CO},(\mathrm{ppm})$ and the specific activities of the latter $(\mathrm{dpm}$ $\mu \mathrm{mol}^{-1}$ ) were as follows: $0,478,4.75 \times 10^{5} ; 1,467,4.82 \times 10^{5} ; 25,472,5.10 \times$ $10^{5} ; 50,507,5.12 \times 10^{5} ; 75,476,5.02 \times 10^{5}$; and $100,435,5.25 \times 10^{5}$, respective- 


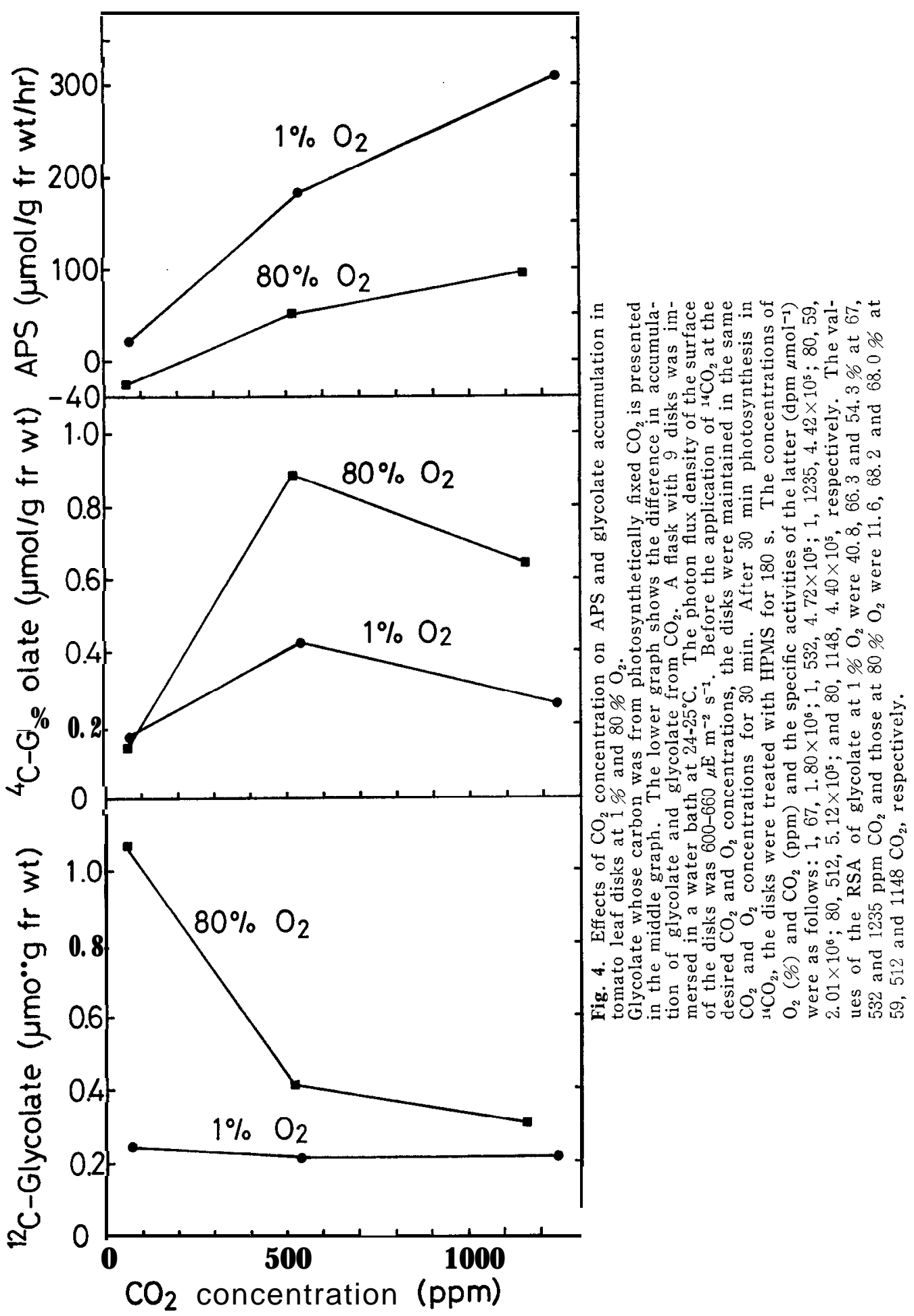


Glycolate ( $\mu \mathrm{mol} / \mathrm{g}$ fr wt)

$\operatorname{RSA}(\%)$

APS ( $\mu \mathrm{mol} / \mathrm{g} \mathrm{fr} w \mathrm{t} / \mathrm{hr})$

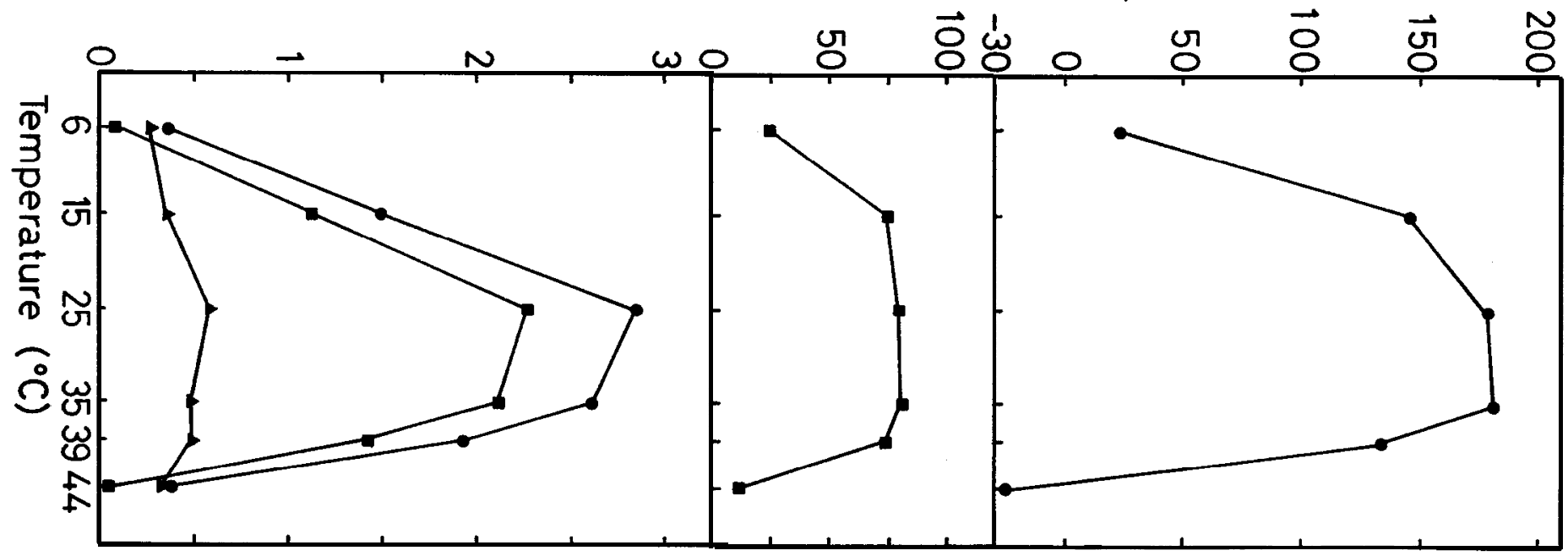

Fig. 5. Effects of temperature on APS, RSA of glycolate and its accumula-

tion in tomato leaf disks.

$\Delta$ indicates the difference in accumulations of glycolate (O) and glycolate

whose carbon was from photosynthetically fixed CO, (D). A flask with 9 disks was immersed in a water bath at the indicated temperatures. The photon flux density at the surface of the disks was about $470 \mu \mathrm{E} \mathrm{m}^{-2} \mathrm{~s}^{-1}$. Before application of ${ }^{14} \mathrm{CO}_{2}$ at each respective temperature, the disks were maintained in ${ }^{12} \mathrm{CO}_{2}$ at the same temperature for 30 min. After $30 \mathrm{~min}$ photosynthesis in ${ }^{14} \mathrm{CO}_{2}$, the disks were treated with HPMS for $180 \mathrm{~s}$. The concentration of ${ }^{14} \mathrm{CO}_{2}$ applied was $386 \mathrm{ppm}$ and its specific activity was

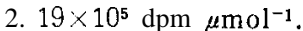




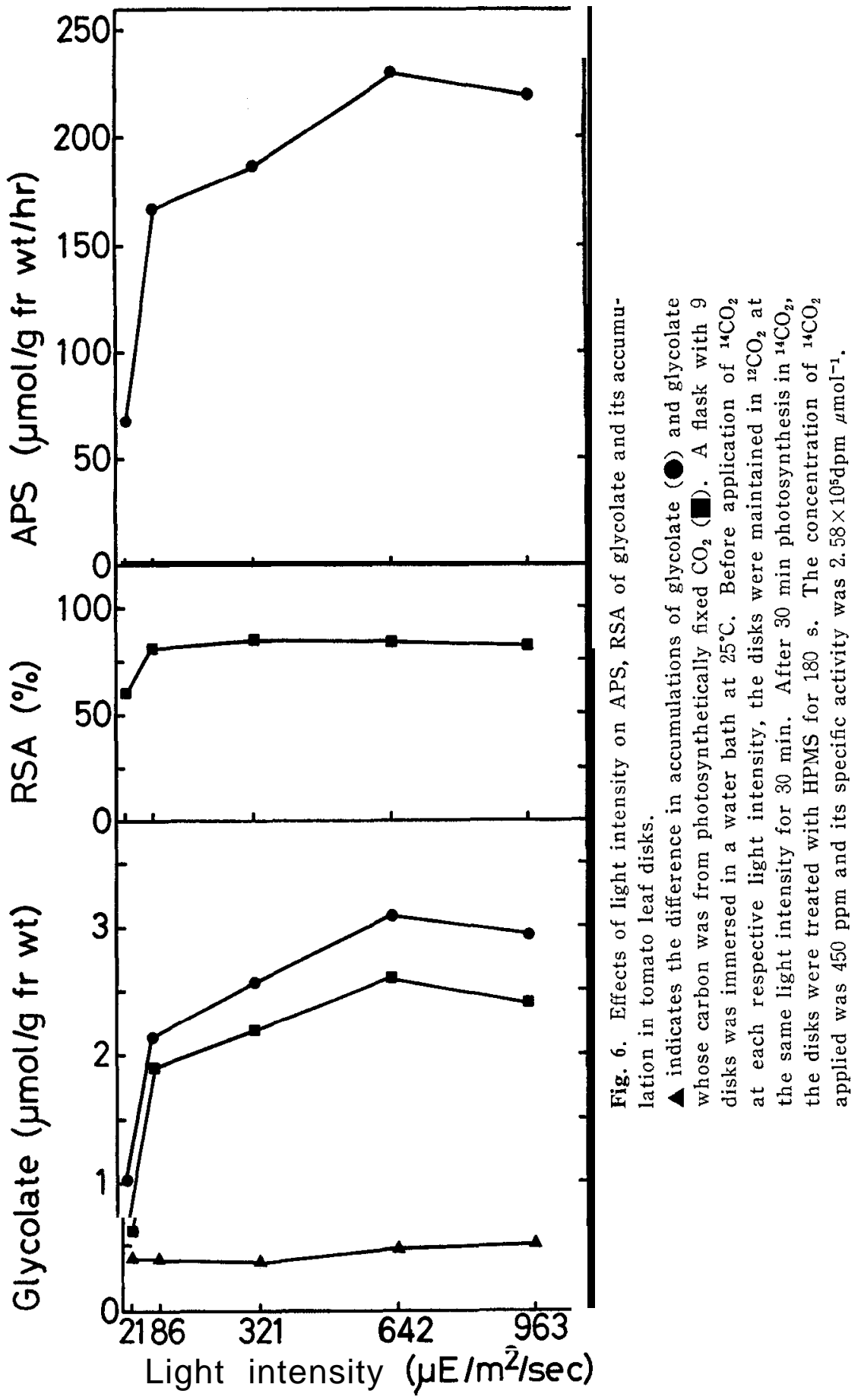


which contradicts the conclusions obtained from organellae. Decreased APS under those conditions could restrict the glycolate synthesis whose carbon is in photosynthesis.

Glycolate synthesis at low CO, concentrations occurred from storage material at $21 \%$ and $80 \% 0$, (Figs. 2 and 4). In the presence of more than 300 ppm $\mathrm{CO}_{2}$, storage material was not used appreciably for glycolate synthesis even when the $\mathrm{O}_{2}$ concentration was $100 \%$ (Fig. 3). These phenomena could be explained by the ratio of $\mathrm{O}_{2} / \mathrm{CO}_{2}$ in the tissue. When APS is close to zero, the concentration of $\mathrm{CO}$, in the leaf tissue would be equal to that surrounding the leaf. The ratios of $\mathrm{O}_{2} / \mathrm{CO}_{2}$ in the tissue became 4200 at $21 \% \mathrm{O}_{2}$ and 50 ppm $(0.005 \%) \mathrm{CO}_{2}$ (Fig. 2) and 4000 at $80 \% \mathrm{O}_{2}$ and 200 ppm $(0.02 \%) \mathrm{CO}$, (Fig. 4), where storage material was involved in the glycolate synthesis. On the other hand, the ratio was 2300 at $100 \% 0$, and 430 ppm $(0.043 \%) \mathrm{CO}$, (Fig. 3), when less storage material was used. Thus, storage material can be involved in glycolate synthesis as the ratio of $\mathrm{O}_{2} / \mathrm{CO}_{2}$ increases, compensating the decreased glycolate synthesis from photosynthetically fixed carbon.

Even when the external CO, supply is limited by environmental conditions, such as water-stress causing stomata 1 closure, photorespiration may continue in illuminated leaves using storage material as a carbon source for gly. colate synthesis. Photorespiratory $\mathrm{CO}_{2}$ evolved in the leaf under such conditions would protect the tissue against photoinhibition (Powles et al., 1979) and/ or photooxidative damage (Asami and Akazawa, 1978) through the dissipation of excess photochemical energy.

\section{ACKNOWLEDGEMENTS}

The authors wish to thank Associate Prof. Dr. Motoki Ikeda for his constructive advice on this study. The present work was supported by Grantsin-Aid (No. 5640010 and 56106015) from the Ministry of Education, Science and Culture, Japan. A Research Fellowship of Japan Society for the Promotion of Science awarded to M. Yamauchi also supported a part of this work.

\section{REFERENCES}

Andrews, T. J. and G. H. Lorimer 1978 Photorespiration -Still unavoidable ? FEBS Lett., 90: $1-9$

Agrawal, P. K. and H. Fock 1978 The specific radioactivity of glycolic acid in relation to the specific activity of carbon dioxide evolved in light in photosynthesizing sunflower leaves. Planta, 138: 257-261

Asami, S. and T. Akazawa 1978 Photooxidative damage in photosynthetic activities of Chromatium uinosum. Plant Physiol., $62: 981-986$

Beck, E. 1979 Glycolate synthesis. In "Photosynthesis II. Photosynthetic carbon metabolism and related processes. Encyclopedia of Plant Physiology." New Series, volume 6. ed. by M. Gibbs and E. Latzko. Springer-Verlag, Berlin, pp. 327-337.

Bravdo, B. A. and D. T. Canvin 1979 Effect of carbon dioxide on photorespiration. Plant Physiol., 63 : 399-401

Calkins, V. P. 1943 Microdetermination of glycolic acid and oxalic acids. Anal.Chem., 15: 
762-763

Ellyard, P. W. and M. Gibbs 1969 Inhibition of photosynthesis by oxygen in isolated spinach chloroplasts. Plant Physiol., 44 : 1115-1121

Fock, H., K. Klug and D. T. Canvin 1979 Effect of carbon dioxide and temperature on photosynthetic CO, uptake and photorespiratory CO, evolution in sunflower leaves. Planta, $145: 219-223$

Lee, R. B. and C. P. Whittingham 1974 The influence of partial pressure of carbon dioxide upon carbon metabolism in the tomato leaf. J.Exp. Bot., 25: 277-287

Ludwig, L. J. and D. T. Canvin 1971 The rate of photorespiration during photosynthesis and the relationship of the substrate of light respiration to the products of photosynthesis in sunflower leaves. Plant Physiol., 48: 712-719

Lüttge, V., C. B. Osmond, E. Ball, E. Brinkmann and G. Kinze 1972 Bisulfite compounds as metabolic inhibitors: Nonspecific effects on membranes. Plant and Cell Physiol., 13: 505-514

Mahon, J. D., H. Fock and D. T. Canvin 1974a Changes in specific radioactivity of sunflower leaf metabolites during photosynthesis in ${ }^{14} \mathrm{CO}_{2}$ and ${ }^{12} \mathrm{CO}_{2}$ at three concentrations of CO,. Planta, 120: 245-254

Mahon, J. D., H. Fock and D. T. Canvin 1974 b Changes in specific radioactivities of sunflower leaf metabolites during photosynthesis in ${ }^{14} \mathrm{CO}_{2}$ and ${ }^{12} \mathrm{CO}_{2}$ at normal and low oxygen. Planta, 120: 125-134

Oliver, D. J. 1979 The interaction between $\mathrm{O}_{2}$ and $\mathrm{CO}$, concentrations on the regulation of glycolate synthesis in tobacco leaf disks. Plant Science Lett., 15: 35-40

Powles, S. B., C. B. Osmond and S. W. Thorne 1979 Photoinhibition of intact attached leaves of $\mathrm{C}_{3}$ plants illuminated in the absence of both carbon dioxide and of photorespiration. Plant Physiol., 64: 982-988

Robinson, J. M. and M. Gibbs 1974 Photosynthetic intermediates, the Warburg effect, and glycolate synthesis in isolated spinach chloroplasts. Plant Physiol., 53: 790-797

Tolbert, N. E. 1971 Microbodies-Peroxisomes and glyoxisomes. Ann. Rev. Plant Physiol., 22: $45-96$

Yamauchi, M. 1982 Regulation of photorespiration by carbon dioxide. PhD. Thesis, Kyushu University.

Yamauchi, M. and Y. Yamada 1980 Effect of CO, concentration on photorespiration, sucrose synthesis, and carbon transport in $\mathrm{C}_{3}$ and $\mathrm{C}_{4}$ plants. Soil Sci. Plant Nutr., 26: 191 $-204$

Yamauchi, M. and Y. Yamada 1981 Glycolate pathway and serine synthesis in relation to CO, concentration in tomato leaves. Plant \& Cell Physiol., 22: 1489-1498

Yamauchi, M. and Y. Yamada 1982 Photorespiratory CO, release from $L-\left[U-{ }^{14} \mathrm{C}\right]$ serine in tomato leaves. Soil Sci. Plant Nutr., 28: 99-107

Zelitch, I. 1973 Alternate pathways of glycolate synthesis in tobacco and maize leaves in relation to rates of photorespiration. Plant Physiol., 51: 299-305

Zelitch, I. 1975 Pathways of carbon fixation in green plants. Ann. Rev. Biochem., 44: 123145

Zelitch, I. 1979 Photorespiration : Studies with whole tissue. In "Photosynthesis II. Photosynthetic carbon metabolism and related processes. Encyclopedia of Plant Physiology". New series, volume 6. ed. by M. Gibbs and E. Latzko. Springer-Verlag, Berlin, pp. 353367.

Zelitch, I. and D. A. Walker 1964 The role of glycolic acid metabolism in opening of leaf stomata. Plant Physiiol., 39: 856-862 